\title{
Calmodulin and calmodulin-dependent protein kinase II inhibit hormone secretion in human parathyroid adenoma
}

\author{
Ming Lu ${ }^{1,2,3}$, Erik Berglund ${ }^{1}$, Catharina Larsson ${ }^{1,3}$, Anders Höög $^{4}$, Lars-Ove Farnebo ${ }^{1}$ \\ and Robert Bränström ${ }^{1}$ \\ ${ }^{1}$ Department of Molecular Medicine and Surgery, Karolinska Institutet, Karolinska University Hospital L1:03, SE-171 76 Stockholm, Sweden \\ ${ }^{2}$ Department of Geriatric Endocrinology, First Affiliated Hospital of Guangxi Medical University, NanNing, People's Republic of China \\ ${ }^{3}$ Center for Molecular Medicine (CMM), Karolinska University Hospital, SE-171 76 Stockholm, Sweden \\ ${ }^{4}$ Department of Oncology-Pathology, Karolinska Institutet, Karolinska University Hospital, SE-171 76 Stockholm, Sweden \\ (Correspondence should be addressed to M Lu at Department of Molecular Medicine and Surgery, Karolinska Institutet, Karolinska University Hospital; \\ Email: ming.lu.1@ki.se)
}

\begin{abstract}
Intracellular calcium $\left(\left[\mathrm{Ca}^{2+}\right]_{\mathrm{i}}\right)$ is the most relevant modulator of parathyroid hormone (PTH) secretion. Uniquely, an increase in $\left[\mathrm{Ca}^{2+}\right]_{i}$ results in an inhibition of $\mathrm{PTH}$ secretion, and it probably exerts its function via calcium-binding protein pathways. The ubiquitous calcium-binding proteins, calmodulin and calmodulin-dependent protein kinase II (CaMKII), have well-established roles in regulated exocytosis in neurons and neuroendocrine cells. However, their roles in parathyroid cells and PTH secretion are still unclear. Using reverse transcription-PCR and western blot analysis, we have demonstrated the expression of calmodulin and CaMKII in human normal parathyroid and parathyroid chief cell adenomas. Blocking of calmodulin and CaMKII activity by the specific antagonists calmidazolium and $\mathrm{KN}-62$ respectively caused a rise in PTH secretion from parathyroid
\end{abstract}

adenoma cells in spite of increased $\left[\mathrm{Ca}^{2+}\right]_{\mathrm{i}}$. The inhibitory effect of $\mathrm{Ca}^{2+}$ calmodulin on PTH secretion may be due to the absence of synaptotagmin 1 protein in parathyroid adenomas, as demonstrated by western blot analysis. An increased extracellular calcium level acutely lowered the amount of active phosphorylated CaMKII (pCaMKII) in adenoma cells in vitro, indicating the physiological importance of this pathway. Moreover, a negative correlation between the levels of pCaMKII in parathyroid adenomas and serum calcium was found in 20 patients with primary hyperparathyroidism. Taken together, these results show that calmodulin negatively contributes to the regulation of PTH secretion in parathyroid adenoma, at least partially via a CaMKII pathway.

Journal of Endocrinology (2011) 208, 31-39

\section{Introduction}

The parathyroid glands are important organs for calcium regulation in the human body. Parathyroid cells sense small changes in serum calcium levels and adjust parathyroid hormone (PTH) secretion to keep serum calcium within a narrow range. In this sense, parathyroid cells are unique because intracellular $\mathrm{Ca}^{2+}\left(\left[\mathrm{Ca}^{2+}\right]_{i}\right)$ inhibits PTH secretion, instead of stimulating secretion as in other endocrine cell types (Shoback et al. 1983). The calcium-sensing receptor (CaSR) is a G-protein-coupled receptor located in the cell membrane. Upon binding of extracellular calcium $\left(\left[\mathrm{Ca}^{2+}\right]_{\mathrm{e}}\right)$ to CaSR, a phospholipase $\mathrm{C}$-inositol triphosphate pathway is activated, resulting in several fold increase in $\left[\mathrm{Ca}^{2+}\right]_{\mathrm{i}}$ and subsequent inhibition of PTH secretion. $\left[\mathrm{Ca}^{2+}\right]_{i}$ has been established as the central second messenger for PTH secretion (Shoback et al. 1984), involving, e.g. the PLA2-AA and the MAP kinase pathways (Kifor et al. 2001, Almaden et al. 2002).
In addition to that, the mechanism behind $\left[\mathrm{Ca}^{2+}\right]_{\mathrm{i}}$ increase and PTH inhibition remains unclear.

Calmodulin is a calcium-binding protein involved in the sensing of increased $\left[\mathrm{Ca}^{2+}\right]_{i}$ concentrations and subsequent signal transduction to a variety of cellular targets. Calmodulin-dependent protein kinase II (CaMKII) is a calmodulin-binding protein participating in functions such as exocytosis, $\left[\mathrm{Ca}^{2+}\right]_{\mathrm{i}}$ oscillation, and ion-channel activation (Wang 2008). Calmodulin is ubiquitously expressed and has been detected in both normal and pathological parathyroid (Brown et al. 1981). However, a correlation between levels of calmodulin expression, calcium sensitivity, and PTH secretion has not been demonstrated (Brown et al. 1981, Oldham et al. 1982). Expression of CaMKII has also been reported in hyperfunctioning human parathyroid cells where modulation of CaMKII activity was found to be calcium and calmodulin dependent (Kinder et al. 1987, Kato et al. 1991). However, the interaction between calcium, 
calmodulin, and CaMKII in human parathyroid has not been clarified. In this study, we have investigated the relationship between calmodulin and CaMKII activity and PTH secretion.

\section{Materials and Methods}

\section{Parathyroid tissue samples}

Normal parathyroid tissue and parathyroid adenomas were collected with informed consent and ethical approval at the Karolinska University Hospital, Sweden. Histopathological diagnoses were according to the WHO classification (DeLellis et al. 2004). Histopathological examination of representative sections verified a high tumor cell content of the analyzed tissue samples.

\section{Reverse transcription-PCR}

The reverse transcription (RT)-PCR analysis included previously published samples of one normal parathyroid (Juhlin et al. 2010), and four or more parathyroid adenoma samples (Lu et al. 2010) for each gene analyzed. Total RNA was extracted using TRIzol reagent (Invitrogen), purified by DNAse I (Amplification Grade, Invitrogen), and quantified by spectrophotometry. Total RNA $(3 \mu \mathrm{g})$ from each sample was reverse transcribed into $40 \mu \mathrm{l}$ cDNA using the SuperScript III First-Strand Synthesis System for RT-PCR (Invitrogen, Cat. no. 18080-051). In all, $2 \mu \mathrm{l}$ of each cDNA were used for amplification of calmodulin 1, 2, and 3 genes (CALM1, CALM2, and CALM3) and of CaMKII $\alpha, \beta, \gamma$, and $\delta$ genes $(C A M K 2 A, C A M K 2 B, C A M K 2 G$, and $C A M K 2 D)$ with the Platinum Taq DNA polymerase highfidelity kit (Invitrogen). Gene-specific forward and reverse PCR primers (Table 1) were designed in house according to published genomic data and PCR primer design guidelines. $C A M K 2 A, C A M K 2 B, C A M K 2 G$, and CAMK2D have several transcript variants due to alternative splicing. Primers were designed based on the common sequence of each gene; therefore, it does not identify specific transcript variants. The PCR reactions were performed in $20 \mu \mathrm{l}$ reactions with amplification conditions as follows: initial denaturation for $2 \mathrm{~min}$ at $94^{\circ} \mathrm{C}$, followed by 40 cycles of $30 \mathrm{~s}$ at $95^{\circ} \mathrm{C}, 30 \mathrm{~s}$ at $50-55^{\circ} \mathrm{C}$, and $1 \mathrm{~min}$ at $68^{\circ} \mathrm{C}$. Human brain cDNA (Invitrogen, Cat. no. B1110033) was used as a positive control. The PCR products were subsequently size verified by agarose gel electrophoresis and were observed and photographed under u.v. light. To further verify the quality, all PCR products were purified using a PCR purification kit (Qiagen, Cat. no. Q28104) and were sequenced with the assistance of the KISeq core facility at Karolinska Institutet, Stockholm, Sweden.

\section{Western blot analysis}

Twenty previously published parathyroid chief cell adenomas and one normal parathyroid biopsy specimen (Lu et al. 2008) were used for western blot analysis (No. 1-20, Table 2), using previously described methodology (Lu et al. 2008). Total proteins were extracted using 1\% NP-40 lysis buffer supplied with protease inhibitors, and then quantified with a Bio-Rad protein assay. Following separation by SDS-PAGE, proteins were blotted onto nitrocellulose membranes and incubated overnight at $4{ }^{\circ} \mathrm{C}$ with primary antibodies, followed by appropriate secondary antibodies. The following primary antibodies and dilutions were applied: monoclonal rabbit anti-calmodulin that targets the single calmodulin protein commonly encoded by the CALM1, CALM2, and CALM3 genes (EP799Y, Abcam, Cambridge, UK, Cat. no. ab45689) at dilution 1:1000; polyclonal anti-endogenous CaMKII antibody that detects total CaMKII $\alpha$ and $\beta$ subunits levels (Acris, Herford, Germany, Cat. No. AP02774PU-S) at 1:500; polyclonal anti-CaMKIIp-Thr286 antibody specific for the phosphorylated form of CaMKII $\alpha$ and $\beta$ subunits (pCaMKII, Acris, Cat. no. AP2526PU-S) at 1:800; monoclonal anti-synaptotagmin 1 antibody (SYSY, Goettingen,

Table 1 Details and primers used for reverse transcription-PCR of the CALM1-3 and CAMK2A, CAMK2B, CAMK2G, and CAMK2D genes

\begin{tabular}{|c|c|c|c|c|c|c|}
\hline $\begin{array}{l}\text { Gene } \\
\text { symbol }\end{array}$ & $\begin{array}{l}\text { Gene } \\
\text { location }\end{array}$ & $\begin{array}{l}\text { Protein } \\
\text { product }\end{array}$ & $\begin{array}{l}\text { Primer } \\
\text { orientation }\end{array}$ & Primer sequence $\left(5^{\prime}-3^{\prime}\right)$ & $\begin{array}{l}\text { Amplicon } \\
\text { length }(b p)\end{array}$ & $\begin{array}{l}\text { Annealing } \\
\text { temperature }\left({ }^{\circ} \mathrm{C}\right)\end{array}$ \\
\hline CALM1 & $14 q 24-q 31$ & Calmodulin & $\begin{array}{l}\text { Forward } \\
\text { Reverse }\end{array}$ & $\begin{array}{l}\text { CAGATATTGATGGAGACGGA } \\
\text { GAGCACACGAAGTACAAGAG }\end{array}$ & 629 & 51 \\
\hline CALM2 & $2 \mathrm{p} 21$ & Calmodulin & $\begin{array}{l}\text { Forward } \\
\text { Reverse }\end{array}$ & $\begin{array}{l}\text { GACAAAGATGGTGATGGAAC } \\
\text { GTCTTCACTTTGCTGTCATC }\end{array}$ & 394 & 51 \\
\hline CALM3 & $19 q 13.2$ & Calmodulin & $\begin{array}{l}\text { Forward } \\
\text { Reverse }\end{array}$ & $\begin{array}{l}\text { ACAAGGATGGAGATGGCAC } \\
\text { ATCTCATCCACСTCCTCATC }\end{array}$ & 313 & 57 \\
\hline САМК $2 B$ & $7 p 14.3$ & CaMKII $\beta$ subunit & $\begin{array}{l}\text { Forward } \\
\text { Reverse }\end{array}$ & $\begin{array}{l}\text { GAGAGAGAGGCTCGGATCTG } \\
\text { TGTCCACAGGCTTGCCATAC }\end{array}$ & 395 & 56 \\
\hline CAMK2G & $10 q 22$ & CaMKII $\gamma$ subunit & $\begin{array}{l}\text { Forward } \\
\text { Reverse }\end{array}$ & $\begin{array}{l}\text { GACTTCTGAAACATCCAAAC } \\
\text { CACCAGGAGGATATACAGGA }\end{array}$ & 431 & 55 \\
\hline$C A M K 2 D$ & $4 q 26$ & CaMKII $\delta$ subunit & $\begin{array}{l}\text { Forward } \\
\text { Reverse }\end{array}$ & $\begin{array}{l}\text { TAGCAAATCCAAGGGAGCAG } \\
\text { ATGGGTGCTTCAGTGCCTC }\end{array}$ & 377 & 55 \\
\hline
\end{tabular}


Table 2 Clinical characteristics and protein expression levels

Protein expression (ratio)

\begin{tabular}{|c|c|c|c|c|c|c|c|}
\hline \multirow[b]{2}{*}{$\begin{array}{l}\text { Case } \\
\text { number }\end{array}$} & \multirow[b]{2}{*}{$\begin{array}{l}\text { Age at } \\
\text { operation }\end{array}$} & \multirow[b]{2}{*}{$\begin{array}{l}\text { Sex } \\
(M / F)\end{array}$} & \multirow[b]{2}{*}{$\begin{array}{l}\text { Serum } \mathbf{C a}^{2+} \\
\text { total }(\mathrm{mM})\end{array}$} & \multirow[b]{2}{*}{$\begin{array}{l}\text { Serum } \\
\text { PTH (ng/l) }\end{array}$} & \multirow[b]{2}{*}{ Weight (g) } & \\
\hline & & & & & & pCaMKII/ $\beta$-actin & Calmodulin/ $\beta$-actin \\
\hline 1 & 61 & M & $2 \cdot 72$ & 156 & $0 \cdot 84$ & $2 \cdot 40$ & $2 \cdot 32$ \\
\hline 2 & 59 & $\mathrm{~F}$ & $2 \cdot 66$ & 241 & $1 \cdot 92$ & $1 \cdot 47$ & $2 \cdot 02$ \\
\hline 3 & 50 & $\mathrm{~F}$ & $2 \cdot 90$ & 211 & $3 \cdot 07$ & $0 \cdot 43$ & $2 \cdot 46$ \\
\hline 4 & 67 & $\mathrm{~F}$ & $2 \cdot 78$ & 104 & $3 \cdot 07$ & $0 \cdot 51$ & $2 \cdot 20$ \\
\hline 5 & 57 & $\mathrm{~F}$ & $2 \cdot 86$ & 185 & $1 \cdot 52$ & $0 \cdot 48$ & $2 \cdot 94$ \\
\hline 6 & 52 & $\mathrm{~F}$ & $2 \cdot 60$ & 68 & $0 \cdot 56$ & $0 \cdot 21$ & $2 \cdot 11$ \\
\hline 7 & 59 & $\mathrm{~F}$ & $2 \cdot 79$ & 114 & $1 \cdot 06$ & $1 \cdot 28$ & $1 \cdot 57$ \\
\hline 8 & 22 & M & $2 \cdot 67$ & 104 & $1 \cdot 80$ & 0.96 & $1 \cdot 32$ \\
\hline 9 & 63 & $\mathrm{~F}$ & $3 \cdot 19$ & 351 & $7 \cdot 60$ & $0 \cdot 62$ & $1 \cdot 60$ \\
\hline 10 & 54 & $\mathrm{~F}$ & $2 \cdot 88$ & & $2 \cdot 10$ & 1.97 & $1 \cdot 42$ \\
\hline 11 & 61 & M & & 83 & $1 \cdot 78$ & $1 \cdot 68$ & $1 \cdot 29$ \\
\hline 12 & 66 & $\mathrm{~F}$ & $2 \cdot 98$ & 234 & $1 \cdot 70$ & $0 \cdot 76$ & $1 \cdot 36$ \\
\hline 13 & 58 & $\mathrm{~F}$ & $2 \cdot 97$ & 358 & $8 \cdot 50$ & $0 \cdot 37$ & $1 \cdot 26$ \\
\hline 14 & 74 & M & $2 \cdot 80$ & 879 & $1 \cdot 10$ & 1.06 & $1 \cdot 33$ \\
\hline 15 & 75 & M & $2 \cdot 42$ & 125 & $3 \cdot 15$ & $1 \cdot 22$ & $1 \cdot 40$ \\
\hline 16 & 62 & $\mathrm{~F}$ & $2 \cdot 86$ & 244 & $1 \cdot 54$ & $1 \cdot 46$ & $1 \cdot 24$ \\
\hline 17 & 42 & M & $2 \cdot 82$ & 149 & $4 \cdot 28$ & 0.78 & $1 \cdot 82$ \\
\hline 18 & 62 & $\mathrm{~F}$ & $3 \cdot 07$ & 424 & $5 \cdot 07$ & $0 \cdot 34$ & $1 \cdot 57$ \\
\hline 19 & 84 & $\mathrm{~F}$ & $2 \cdot 96$ & 596 & $1 \cdot 92$ & $0 \cdot 78$ & $1 \cdot 39$ \\
\hline 20 & 90 & $\mathrm{~F}$ & $3 \cdot 26$ & 485 & $6 \cdot 28$ & $0 \cdot 16$ & $1 \cdot 58$ \\
\hline
\end{tabular}

Reference values: serum $\mathrm{Ca}^{2+}(2 \cdot 20-2 \cdot 60 \mathrm{mM}), \mathrm{PTH}(10-65 \mathrm{ng} / \mathrm{l})$. Clinical characteristics have been published in Lu et al. (2008).

Germany, Cat. no. 105011) at 1: 1000; and anti- $\beta$-actin (Sigma, Cat. no. A5441) used as a protein loading control. The results were visualized using enhanced chemiluminescence and by exposing to hyperfilm. The band density was measured by ImageJ software (NIH, Bethesda, Maryland, USA), and the levels of pCaMKII and calmodulin were determined by normalization against the density of $\beta$-actin.

\section{Preparation of parathyroid adenoma cells}

Fresh parathyroid adenoma tissues were collected at operation, quickly transferred to the laboratory in ice-cold MEM medium, and digested into cells with $1.5 \mathrm{mg} / \mathrm{ml}$ type II collagenase and $0 \cdot 1 \mathrm{mg} / \mathrm{ml} \mathrm{DNase}$. The cells were cultured in DMEM/F-12 (GlutaMAX, Gibco) supplied with 10\% FCS and 1\% penicillinstreptomycin for either $\left[\mathrm{Ca}^{2+}\right]_{\mathrm{i}}$ measurement or PTH secretion studies. All experiments were performed within $72 \mathrm{~h}$ after isolation. Calmidazolium was purchased from Sigma, and KN-62 was obtained from Calbiochem (San Diego, CA, USA). Stock solutions were prepared in DMSO, and the final concentration of DMSO was $<1 \%$.

\section{Measurement of $\left[\mathrm{Ca}^{2+}\right]_{i}$ by Fura-2}

After isolation, parathyroid adenoma cells were grown on glass cover slides overnight until they attached. Cells were loaded with $2.5 \mu \mathrm{M}$ Fura-2 AM (Invitrogen) at $37^{\circ} \mathrm{C}$ for $30 \mathrm{~min}$ in extracellular solution (EC) containing (in $\mathrm{mM}$ ): $125 \mathrm{NaCl}, 4 \mathrm{KCl}, 1 \mathrm{MgCl}_{2}, 0 \cdot 8 \mathrm{NaH}_{2} \mathrm{PO}_{4}, 20 \mathrm{HEPES}$, and $5.6 \mathrm{D}$-glucose with $1.0 \mathrm{CaCl}_{2}$. Slides were mounted into a $37^{\circ} \mathrm{C}$ perfusion chamber and exposed to an inverted fluorescence microscope (Axiovert 135 TV, Zeiss, Oberkochen, Germany) with a $\times 40$ oil objective. Fluorescence was provided by a SPEX fluorolog-2 CM1T11I spectrofluorimeter (SPEX Industries, Edison, NJ, USA) with the excitation wavelengths at 340 and $380 \mathrm{~nm}$, and emission was monitored at $505 \mathrm{~nm}$. Fluorescence imaging was detected by a cooled charge-coupled device camera (CCD, CH250 with KAF 1400, Photometrics, Tucson, AZ, USA) connected to an imaging system (Inovision, Durham, NC, USA). Fluorescence intensity was analyzed by ISEE software for UNIX (Inovision). The ratio of $340 / 380 \mathrm{~nm}$ emitted fluorescence was calculated to represent the $\left[\mathrm{Ca}^{2+}\right]_{\mathrm{i}}$ level.

\section{Measurement of PTH secretion}

Parathyroid adenoma cells were suspended in the medium overnight, allowing them to recover from collagenase digestion. Cell viability, assessed using Trypan blue, was $>98 \%$. Cells $\left(1 \times 10^{4}-1 \times 10^{5}\right)$ were loaded into a column on the top of a $3 / 5$ volume of P-4 gel. The column was carefully closed and kept in a cabinet with a constant temperature of $37^{\circ} \mathrm{C}$. A peristaltic pump at a speed of $500 \mu \mathrm{l} / 3 \mathrm{~min}$ effectuated perfusion of the column. A $30 \mathrm{~min}$ preperfusion with EC containing $1.5 \mathrm{mM} \mathrm{Ca}^{2+}$ and basal amino acid, as previously described (Conigrave et al. 2004), was run before every experiment. Samples were collected every $3 \mathrm{~min}$, quickly put on ice, and stored at $-20{ }^{\circ} \mathrm{C}$ until use for PTH quantifications. Intact PTH was measured using an electrochemiluminescense immunoassay (Roche, Cat. no.11972219) at the routine clinical chemistry laboratory of Karolinska University Hospital. Each protocol was performed at least 
A

A

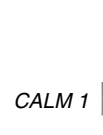

$P$ \begin{tabular}{llll}
\multicolumn{4}{c}{ Adenoma } \\
\hline 19 & 5 & 12 & 15
\end{tabular}

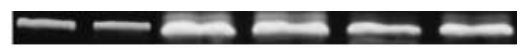

629 bp

CALM 2

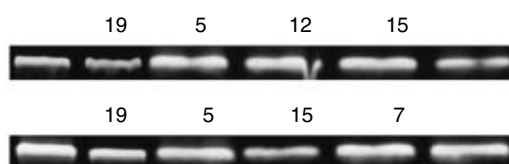

394 bp

CALM 3

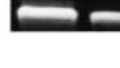

CaMK2A

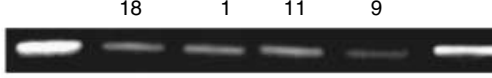

$\begin{array}{llll}19 & 5 & 11 & 9\end{array}$

CaMK2B

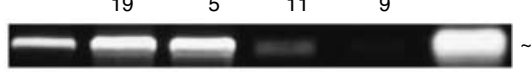

11

CaMK2G

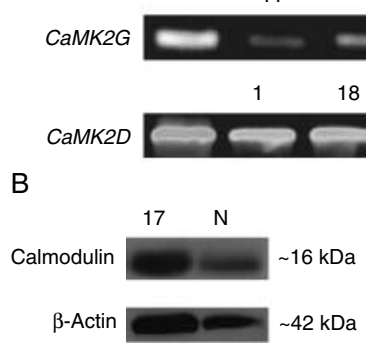

Figure 1 Expression of calmodulin and CaMKII in human parathyroid. (A) RT-PCR analysis for agarose gel electrophoresis showing products of CALM1-3, CAMK2A, CAMK2B, CAMK2G, and CAMK2D genes in normal $(\mathrm{N})$ and adenoma parathyroids, and human brain $(\mathrm{P})$ used as control. Products were verified by sequencing expected for CAMK2A in parathyroid adenoma and normal. (B) Autoradiograms of western blots demonstrate protein expression of calmodulin and total CaMKII at expected product sizes in both normal and adenoma parathyroid.

three times from at least two different adenoma glands. To allow comparison, the initial PTH level in each experiment was set to the arbitrary value of 1 , and the PTH levels were normalized correspondingly.

Short-term treatment of parathyroid adenoma cells with calcium

To investigate the effect of $\left[\mathrm{Ca}^{2+}\right]_{\mathrm{e}}$ on calmodulin and active pCaMKII, parathyroid adenoma cells were incubated with EC supplied with $0 \cdot 5,1 \cdot 2$, or $2 \cdot 5 \mathrm{mM} \mathrm{Ca}^{2+}$ for 20 or $60 \mathrm{~min}$ respectively. After treatment, cells were washed twice with cold PBS, and then extracted for proteins. Untreated cells were used as negative control. The levels of calmodulin and pCaMKII were determined using western blot analysis.

\section{Statistical analysis}

All data are given as the mean \pm s.D. If not indicated otherwise, experiments were repeated at least three times. Statistical significance was analyzed using paired and unpaired $t$-tests between the two groups or ANOVA and post hoc test for multiple groups. Nonparametric tests were used to compare protein expression levels with clinical parameters. A $P$ value of $<0.05$ was considered significant.

\section{Results}

Expression of calmodulin and CaMKII in human parathyroid

Expression of the three calmodulin-encoding genes, CALM1, CALM2, and CALM3, and CAMK2 genes was demonstrated by RT-PCR. As illustrated in Fig. 1A, single products of expected sizes were successfully amplified for CALM1, CALM2, CALM3, CAMK2A, CAMK2B, $C A M K 2 G$, and $C A M K 2 D$ from human brain cDNA (positive control) and verified as correct by DNA sequencing. Products of the same sizes as the positive control were also amplified in parathyroid normal and adenoma samples. For all genes, except $C A M K 2 A$, the products were subsequently verified as correct by sequencing. Products amplified from parathyroid adenoma and normal tissue with $C A M K 2 A$ primers were found to have the sequence of $C A M K 2 B$, suggesting that $C A M K 2 A$ is not expressed in human parathyroid. Western blot analysis confirmed the expression of calmodulin and CaMKII on the protein level in normal and adenoma parathyroid samples (Fig. 1B).
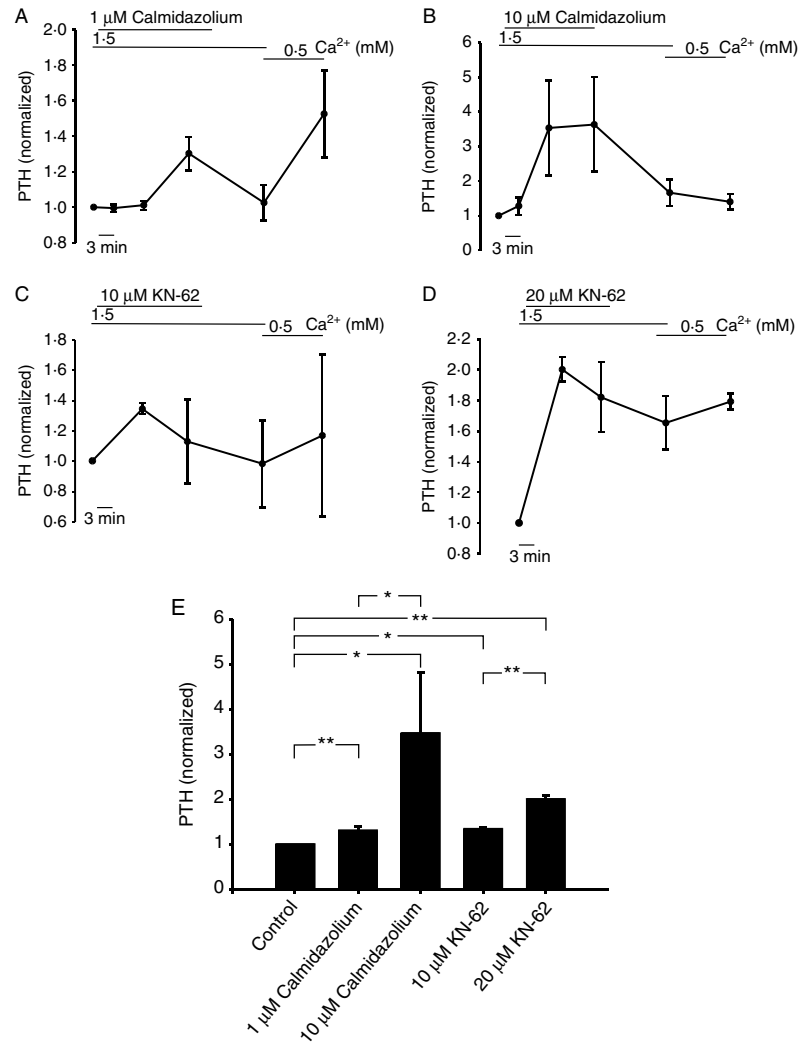

Figure 2 Effect of calmidazolium and $\mathrm{KN}-62$ on PTH secretion. (A-D) Addition of 1 and $10 \mu \mathrm{M}$ calmidazolium and 10 and $20 \mu \mathrm{M}$ $\mathrm{KN}-62$ at $1.5 \mathrm{mM} \mathrm{Ca}^{2+}$ caused an increase in PTH secretion. As summarized in (E), calmidazolium and $\mathrm{KN}-62$ increased PTH secretion in a dose-dependent manner $\left({ }^{*} P<0 \cdot 05 ; * * P<0 \cdot 01\right)$. The bars refer to time points of maximal observed effect. 
Association of calmodulin and CaMKII with PTH secretion

The calmodulin antagonist calmidazolium was used to inhibit the calmodulin-regulated activity, and KN-62 was used to inhibit CaMKII activity. Parathyroid adenoma cells were loaded into a perfusion column and preperifused for $30 \mathrm{~min}$ with EC containing $1.5 \mathrm{mM} \mathrm{Ca}^{2+}$ before starting the experimental protocol. Thereafter, all experiments started with a 9 min perfusion of $1.5 \mathrm{mM} \mathrm{Ca}^{2+}$, followed by an addition of drugs for $18 \mathrm{~min}$. After washout, $0.5 \mathrm{mM} \mathrm{Ca}^{2+}$ was administered to verify parathyroid cell viability. Calmidazolium was tested at concentrations of 1 and $10 \mu \mathrm{M}$, and KN-62 was tested at 10 and $20 \mu \mathrm{M}$. Results are presented individually in Fig. 2A-D. In summary (Fig. 2E), $1 \mu \mathrm{M}$ calmidazolium caused a $30 \pm 9 \cdot 4 \%$ increase in PTH secretion, whereas $10 \mu \mathrm{M}$ calmidazolium led to a $260 \pm 130 \%$ rise in PTH secretion. An addition of $10 \mu \mathrm{M}$ KN-62 resulted in a $34 \pm 4 \%$ increase in PTH secretion, and $20 \mu \mathrm{M}$ KN-62 caused a $100 \pm 7 \cdot 9 \%$ increase in PTH secretion (Fig. 2E).

\section{The effect of calmidazolium and KN-62 on [Ca $\left.{ }^{2+}\right]_{i}$}

To investigate whether calmodulin and CaMKII are involved in the regulation of $\left[\mathrm{Ca}^{2+}\right]_{i}$ signaling, we used the $\mathrm{Ca}^{2+}$ indicator Fura-2 to examine $\left[\mathrm{Ca}^{2+}\right]_{i}$. Calmidazolium or KN-62 was added to parathyroid adenoma cells through a perfusion system after step stimulation by 0.5 and $1.5 \mathrm{mM}$ $\mathrm{Ca}^{2+}$. As shown in Fig. 3A, no significant change in $\left[\mathrm{Ca}^{2+}\right]_{\mathrm{i}}$ was observed after adding $1 \mu \mathrm{M}$ calmidazolium. An elevation of $\left[\mathrm{Ca}^{2+}\right]_{\mathrm{i}}$ was observed after giving $10 \mu \mathrm{M}$ calmidazolium. In the absence of $\mathrm{Ca}^{2+}, 10 \mu \mathrm{M}$ calmidazolium only caused a small transient increase in $\left[\mathrm{Ca}^{2+}\right]_{i}$, but the addition of $1.5 \mathrm{mM} \mathrm{Ca}^{2+}$ resulted in a higher rise of $\left[\mathrm{Ca}^{2+}\right]_{i}$ than without the drug (Fig. 3B). Administration of 10 and $20 \mu \mathrm{M}$ KN-62 did not show any effect on $\left[\mathrm{Ca}^{2+}\right]_{\mathrm{i}}$ (Fig. 3C).

Negative correlation between $p$ CaMKII and serum calcium levels

To investigate the possible correlation between calmodulin and CaMKII levels and clinical pathological data, we analyzed the protein expression of calmodulin and the active form of CaMKII (pCaMKII) in 20 parathyroid chief cell adenomas. Calmodulin and pCaMKII were quantified by normalization to $\beta$-actin levels (Table 2). Clinical data for the 20 patients with primary hyperparathyroidism were: age at diagnosis $61 \cdot 5 \pm 14 \cdot 7$ years, total serum $\mathrm{Ca}^{2+} 2 \cdot 85 \pm 0 \cdot 20 \mathrm{mM}$, serum PTH level $269 \pm 208 \mathrm{ng} / 1$, and tumor weight $2 \cdot 8 \pm 2 \cdot 3 \mathrm{~g}$ (for details, see Table 2). Calmodulin was clearly expressed at comparable levels in all parathyroid adenomas, whereas the amount of pCaMKII showed a larger variation between the samples (Fig. 4A; Table 2). In our material, calmodulin protein levels were not found to correlate with serum $\mathrm{Ca}^{2+}$, PTH, or tumor weight. In 8 out of 20 parathyroid adenomas, the pCaMKII signal was weak (Fig. 4A; Table 2). There was a negative correlation between the patients' total serum $\mathrm{Ca}^{2+}$ levels and the pCaMKII levels in the parathyroid adenomas

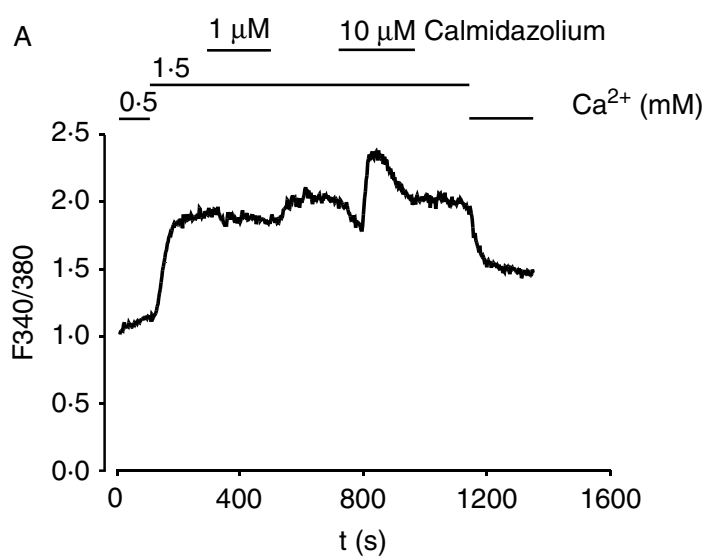

B $10 \mu \underline{\mathrm{M} \text { Calmidazolium }}$
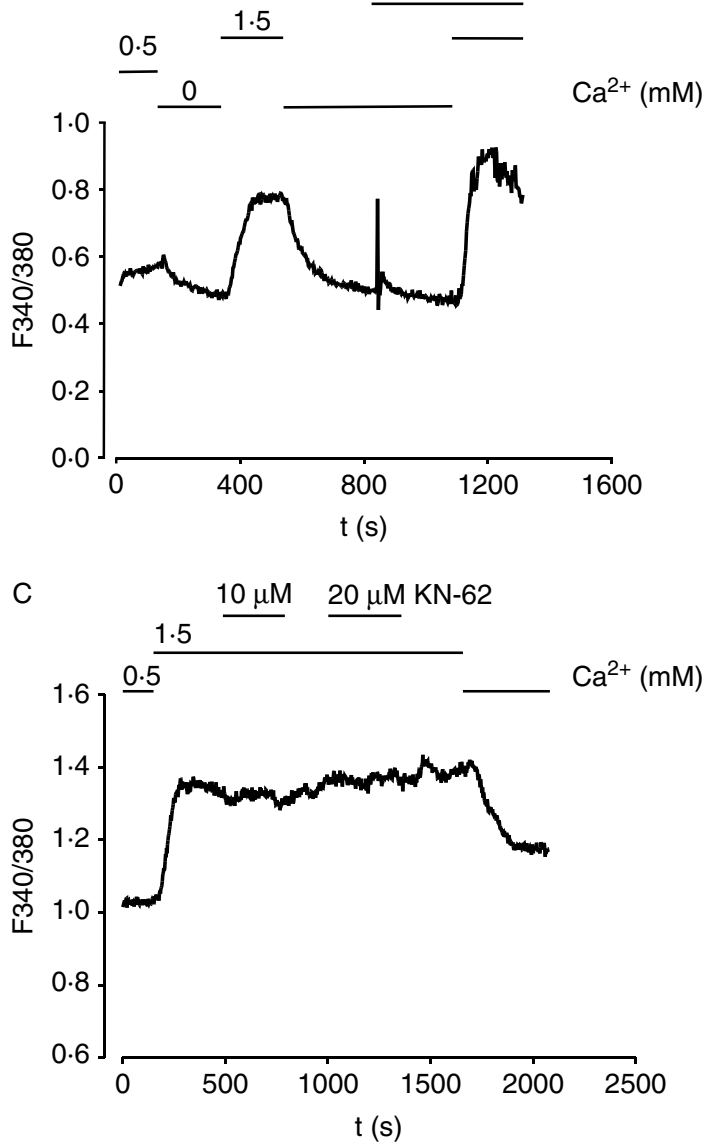

Figure 3 Measurement of $\left[\mathrm{Ca}^{2+}\right]_{\mathrm{i}}$ using Fura-2 and determination of ratios for 340/380 nm emitted fluorescence (F340/380).

(A) Application of $1 \mu \mathrm{M}$ calmidazolium did not cause a significant change of $\left[\mathrm{Ca}^{2+}\right]_{\mathrm{i}}$, however, $10 \mu \mathrm{M}$ calmidazolium induced an increase in $\left[\mathrm{Ca}^{2+}\right]_{i}$. (B) In the absence of $\mathrm{Ca}^{2+}, 10 \mu \mathrm{M}$ calmidazolium only induced a small transient increase in $\left[\mathrm{Ca}^{2+}\right]_{i}$, however, addition of $1.5 \mathrm{mM} \mathrm{Ca}^{2+}$ caused a higher constant increase in $\left[\mathrm{Ca}^{2+}\right]_{i} ;(\mathrm{C}) 10$ and $20 \mu \mathrm{M} \mathrm{KN}-62$ had no effect on $\left[\mathrm{Ca}^{2+}\right]_{i}$. 

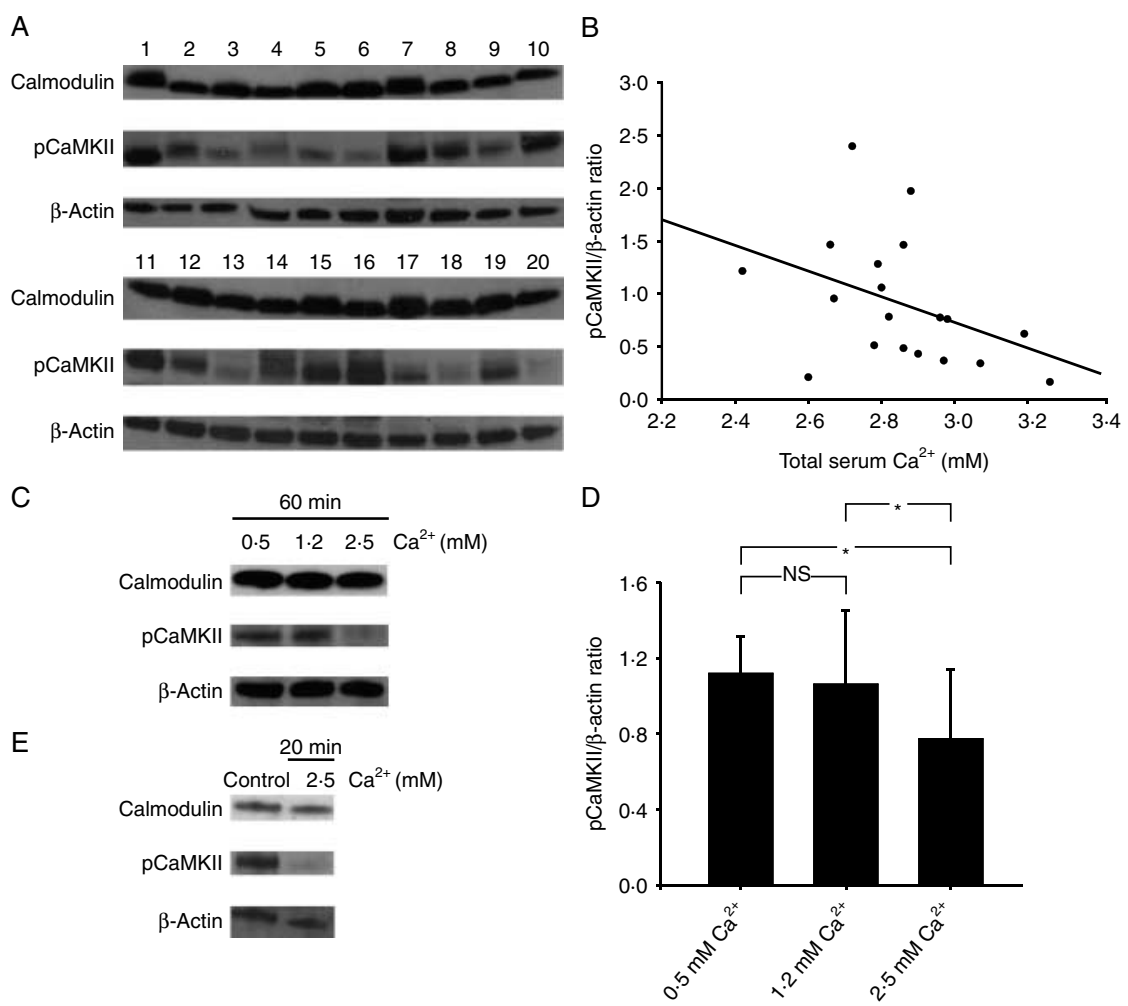

Figure 4 Demonstration of phospharylated CaMKII (pCaMKII) expression in parathyroid adenoma. (A) Western blot analysis of calmodulin and pCaMKII (pT286) protein in 20 parathyroid adenomas (No. 1-20). $\beta$-Actin served as loading control. (B) There was a negative correlation between total serum $\mathrm{Ca}^{2+}$ and pCaMKII in the tumors. (C) The amount of pCaMKII in human parathyroid adenoma cells was reduced when extracellular $\mathrm{Ca}^{2+}$ was increased during $1 \mathrm{~h}$ incubation whereas no change on calmodulin was seen with the same treatment. The effect on pCaMKII level at different extracellular $\mathrm{Ca}^{2+}$ concentrations is summarized in (D) $\left({ }^{*} P<0 \cdot 05\right.$, NS $\left.P>0 \cdot 05\right)$. (E) The amount of pCaMKII at $2.5 \mathrm{mM} \mathrm{Ca}^{2+}$ was reduced at $20 \mathrm{~min}$.

(Spearman's $\rho, r=-0 \cdot 470, P<0 \cdot 05$; Fig. 4B). No correlation was observed between pCaMKII levels and serum PTH, tumor weight, or calmodulin protein levels. After treating parathyroid adenoma cells with EC containing $0 \cdot 5$, $1 \cdot 2$, and $2.5 \mathrm{mM} \mathrm{Ca}^{2+}$ for $60 \mathrm{~min}$, no difference was observed in the expression of calmodulin protein, but a clear reduction in pCaMKII was detected at $2.5 \mathrm{mM} \mathrm{Ca}^{2+}$ (Fig. 4C and D). The effect could already be demonstrated after $20 \mathrm{~min}$ of incubation (Fig. 4E).

\section{Absence of synaptotagmin 1 in human parathyroid adenomas}

The expression of synaptotagmin 1 was investigated using western blot analysis. A product at the expected molecular size $(\sim 60 \mathrm{kDa})$ was clearly detected in the rat insulinoma INS-1 cell line (Lang et al. 1997) used as positive control. However, the same products were undetectable in all of the human parathyroid adenoma samples investigated (Fig. 5), suggesting that synaptotagmin 1 is rarely expressed in parathyroid adenoma.

\section{Discussion}

$\left[\mathrm{Ca}^{2+}\right]_{\mathrm{i}}$ is the central player for hormone secretion in endocrine cells. Parathyroid cells are not exclusive even though the parathyroid cell distinguishes itself because of the negative regulation by calcium. In the same way as in other endocrine cells, activation of receptors evokes a rise in $\left[\mathrm{Ca}^{2+}\right]_{\mathrm{i}}$ by mobilization of cellular $\left[\mathrm{Ca}^{2+}\right]_{\mathrm{i}}$ and calcium influx. $\left[\mathrm{Ca}^{2+}\right]_{\mathrm{i}}$ of $100-200 \mathrm{nM}$, which is close to the resting $\left[\mathrm{Ca}^{2+}\right]_{\mathrm{i}}$ in other cell types, results in a maximal release of PTH (Shoback et al. 1984). A typical rise of $\left[\mathrm{Ca}^{2+}\right]_{\mathrm{i}}$ induced by increased $\left[\mathrm{Ca}^{2+}\right]_{\mathrm{e}}$ in parathyroid cells is biphasic, including a transient increase followed by a steady-state increase probably via store-operated calcium channels (Lu et al. 2010). Some compounds, such as dopamine, potentiate PTH secretion without changing $\left[\mathrm{Ca}^{2+}\right]_{\mathrm{i}}$ (Nemeth et al. 1986). Therefore, it is likely that additional signaling pathways are involved in PTH secretion. $\left[\mathrm{Ca}^{2+}\right]_{\mathrm{i}}$ signaling involves many $\mathrm{Ca}^{2+}$-binding proteins acting as calcium sensors or adaptors, which transduce signaling to cell processes via enzymatic reactions and protein-protein interaction. 


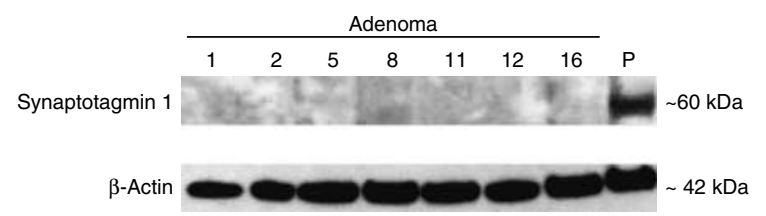

Figure 5 Absence of synaptotagmin 1 expression in human parathyroid adenomas. Western blot analysis demonstrated a product of expected size for synaptotagmin 1 in INS-1 cells (P), but not in human parathyroid adenomas. Subsequent incubation with anti- $\beta$-actin demonstrated equal loading between the lanes.

Calmodulin, the most universal $\mathrm{Ca}^{2+}$-binding protein in eukaryotic cells, has been demonstrated in human parathyroid (Brown et al. 1981, Oldham et al. 1982). These authors found that the amount of calmodulin does not differ between normal parathyroid and parathyroid adenomas (Oldham et al. 1982), but it is increased in secondary hyperparathyroidism (Brown et al. 1981). It is known that the single calmodulin protein is encoded by three genes CALM1, CALM2, and CALM3 (Fischer et al. 1988). By using RT-PCR, we showed expression of all three calmodulin genes in human normal and adenomatous parathyroid tissue. Western blot confirmed its expression at the protein level. By analyzing 20 adenomas, we found that the calmodulin protein level did not correlate with serum $\mathrm{Ca}^{2+}, \mathrm{PTH}$, or tumor weight. Incubation for $60 \mathrm{~min}$ with $0 \cdot 5,1 \cdot 2$, and $2.5 \mathrm{mM} \mathrm{Ca}^{2+}$ did not alter the expression of calmodulin. These findings suggest that the amount of calmodulin is not associated with calcium-regulated PTH secretion, which is in accordance with previous studies (Brown et al. 1981, Oldham et al. 1982). Calmidazolium, a powerful and frequently used calmodulin blocker, was found to cause a significant dose-dependent increase in PTH secretion. Notably, the effect of $10 \mu \mathrm{M}$ calmidazolium was 8.6-fold higher than $1 \mu \mathrm{M}$ calmidazolium. The strong pharmacological action of $10 \mu \mathrm{M}$ calmidazolium may cause emptying of the secretory vesicle pool and result in reduced response to the subsequent stimulation of $0.5 \mathrm{mM} \mathrm{Ca}^{2+}$. These results imply that a calmodulin-regulated pathway is involved in PTH secretion.

Among numerous calmodulin-regulated enzymes, $\mathrm{Ca}^{2+}$ / CaMKII is the best-established calmodulin-regulated kinase participating in exocytosis. CaMKII has four subunits: $\alpha, \beta$, $\gamma$, and $\delta$. It regulates neurotransmitter release (Stefani et al. 1997), insulin secretion (Bhatt et al. 2000, Yamamoto et al. 2003), and catecholamine secretion (Schweitzer et al. 1995) via phosphorylation of synapsin I. By using calmodulin affinity chromatography, CaMKII (only $\alpha$ subunit) has been purified from human parathyroid cells (Kinder et al. 1987, Kato et al. 1991). The function of CaMKII in parathyroid cells has never been investigated. In this paper, we have demonstrated expression of the genes $C A M K 2 B$, $C A M K 2 G$, and $C A M K 2 D$ encoding the CaMKII subunits $\beta, \gamma$ and $\delta$ but not $C A M K 2 A$, which encodes the CaMKII subunit $\alpha$ in human parathyroid using RT-PCR. Inhibition of
CaMKII activity by the specific blocker KN-62 resulted in a dose-dependent increase in PTH secretion. This finding indicates that CaMKII is involved in the regulation of PTH release. The weaker effect of $\mathrm{KN}-62$ compared with calmidazolium suggests that the CaMKII pathway is only partially involved in calmodulin-regulated PTH secretion.

In order to investigate the mechanism of calmodulin and CaMKII-regulated PTH secretion, $\left[\mathrm{Ca}^{2+}\right]_{\mathrm{i}}$ measurements were performed. Our results showed that $1 \mu \mathrm{M}$ calmidazolium caused no significant change in $\left[\mathrm{Ca}^{2+}\right]_{i}$, whereas, surprisingly, $10 \mu \mathrm{M}$ calmidazolium induced an increase in $\left[\mathrm{Ca}^{2+}\right]_{\mathrm{i}}$. No obvious change in $\left[\mathrm{Ca}^{2+}\right]_{\mathrm{i}}$ by 10 or $20 \mu \mathrm{M} \mathrm{KN}-$ 62 was demonstrated. Together with the PTH secretion data, this shows that the stimulation of $\mathrm{PTH}$ secretion by calmidazolium and KN-62 is dissociated from the $\left[\mathrm{Ca}^{2+}\right]_{\mathrm{i}}$ level. It is therefore possible that calmodulin directly influences the final step of hormone secretion, i.e. exocytosis. Calmodulin has been shown to interact with several exocytotic proteins, such as VAMP-2, Munc-13, and rab-3. Several of these exocytotic proteins are expressed in human parathyroid (Lu et al. 2008). Giovanni et al. showed that calmodulin itself has an inhibitory effect on exocytosis, because the binding of calmodulin to VAMP-2 impairs SNARE-mediated membrane fusion. However, when calmodulin is combined with synaptotagmin 1, the calmodulin-synaptotagmin 1 complex will overcome the inhibitory effect of calmodulin and accelerate the membrane fusion (Di Giovanni et al. 2010). These observations suggest that the existence of synaptotagmin 1 has an important role in $\mathrm{Ca}^{2+}$-mediated membrane fusion. Interestingly, we could not detect synaptotagmin 1 in parathyroid adenomas. The absence of synaptotagmin 1 can at least partially give an explanation for the unusual $\mathrm{Ca}^{2+} /$ calmodulin-inhibited hormone secretion in human parathyroid adenoma cells.

Calmidazolium induced an increase in $\left[\mathrm{Ca}^{2+}\right]_{i}$, which is in agreement with previous findings reported in other cell types and species, such as endothelial cells (Watanabe et al. 1999) and hepatoma cells (Schlatterer \& Schaloske 1996, Liao et al. 2009). As shown in Fig. 3B, addition of calmidazolium caused a dramatic increase in $\left[\mathrm{Ca}^{2+}\right]_{i}$ in the presence, but not in the absence, of $\left[\mathrm{Ca}^{2+}\right]_{\mathrm{e}}$. These findings suggest that the mechanism of increased $\left[\mathrm{Ca}^{2+}\right]_{\mathrm{i}}$ by calmidazolium could be due to calcium influx, i.e. induction of $\mathrm{Ca}^{2+}$ leakage from intracellular stores followed by calcium influx. This action has been argued to be unrelated to calmodulin. However, calmodulin was reported to inhibit thapsigargin-induced $\mathrm{Ca}^{2+}$ current (Vaca 1996), interrupt activation of calcium influx through TRPC1 channels (Vaca \& Sampieri 2002), and inhibit $\mathrm{Ca}^{2+}$ release from the endoplasmic reticulum in skeletal muscle (Buratti et al. 1995). These observations suggest that an increased $\left[\mathrm{Ca}^{2+}\right]_{\mathrm{i}}$ induced by calmidazolium, as shown here in human parathyroid adenoma cells, may at least partially be calmodulin dependent.

The pCaMKII is active, whereas the dephosphorylated CaMKII is not. Autophosphorylation at threonine 286 residue increases the $\mathrm{Ca} / \mathrm{CaM}$ affinity to CaMKII and 
prolongs the activated state of CaMKII. Since antibodies against pCaMKII $\gamma$ and $\delta$ are not available, we verified the level of T-286 pCaMKII $\alpha$ and $\beta$. By analyzing 20 chief cell adenomas, we found that the levels of pCaMKII in the tumors were negatively correlated with the patients' total serum $\mathrm{Ca}^{2+}$ levels. In cellular studies, a remarkable reduction in CaMKII activity was seen after incubation of cells with $2.5 \mathrm{mM} \mathrm{Ca}^{2+}$, compared with 0.5 and $1.2 \mathrm{mM} \mathrm{Ca}^{2+}$. Taken together, our results clearly show that high calcium suppresses the CaMKII activity in human parathyroid cells. The pathophysiological role of CaMKII in human parathyroid is still, however, unclear.

In conclusion, our results show that calmodulin and CaMKII are involved in the regulation of PTH secretion. In addition, we show that the amount of active CaMKII, namely pCaMKII, is reduced by increased calcium. Further studies are needed to understand the function of calmodulin/ CaMKII in parathyroid cells.

\section{Declaration of interest}

The authors declare that there is no conflict of interest that could be perceived as prejudicing the impartiality of the research reported.

\section{Funding}

This work was supported by grants from the Swedish Research Council, the Novo Nordisk Foundation, Funds of Karolinska Institutet, the Tore Nilsson Foundation, the Thuring Foundation, the Jeansson Foundations, the Ake Wiberg Foundation, the Göran Gustavsson Foundation for Research in Natural Sciences and Medicine, Magn. Bergvall Foundations, Cancer Research Funds of Radiumhemmet, the Stockholm County Council, the Swedish Cancer Foundation, and the Knut and Alice Wallenberg Foundation.

\section{Acknowledgements}

We thank Elisabet Ånfalk for excellent assistance in sample collection.

\section{References}

Almaden Y, Canalejo A, Ballesteros E, Anon G, Canadillas S \& Rodriguez M 2002 Regulation of arachidonic acid production by intracellular calcium in parathyroid cells: effect of extracellular phosphate. Journal of the American Society of Nephrology 13 693-698.

Bhatt HS, Conner BP, Prasanna G, Yorio T \& Easom RA 2000 Dependence of insulin secretion from permeabilized pancreatic $\beta$-cells on the activation of $\mathrm{Ca}(2+) /$ calmodulin-dependent protein kinase II. A re-evaluation of inhibitor studies. Biochemical Pharmacology 60 1655-1663. (doi:10.1016/ S0006-2952(00)00483-4)

Brown EM, Dawson-Hughes BF, Wilson RE \& Adragna N 1981 Calmodulin in dispersed human parathyroid cells. Journal of Clinical Endocrinology and Metabolism 53 1064-1071. (doi:10.1210/jcem-53-5-1064)

Buratti R, Prestipino G, Menegazzi P, Treves S \& Zorzato F 1995 Calcium dependent activation of skeletal muscle $\mathrm{Ca}^{2+}$ release channel (ryanodine receptor) by calmodulin. Biochemical and Biophysical Research Communications 213 1082-1090. (doi:10.1006/bbrc.1995.2238)
Conigrave AD, Mun HC, Delbridge L, Quinn SJ, Wilkinson M \& Brown EM 2004 L-amino acids regulate parathyroid hormone secretion. Journal of Biological Chemistry 279 38151-38159. (doi:10.1074/jbc.M406373200)

Grimelius L, Auerstrom G, Franssila KO, Eng C, DeLellis RA, Arnold A, Hendy GN, Bondeson L \& Dupuy D 2004 Parathyroid Adenoma. In: DeLellis RA, Lloyd RV, Heitz PU \& Eng C (eds) World Health Organization Classification of Tumours: Pathology and Genetics of Tumours of Endocrine Organs. Lyon: IARC Press, pp 128-133.

Di Giovanni J, Iborra C, Maulet Y, Leveque C, El Far O \& Seagar M 2010 Calcium-dependent regulation of SNARE-mediated membrane fusion by calmodulin. Journal of Biological Chemistry 285 23665-23675. (doi:10.1074/ jbc.M109.096073)

Fischer R, Koller M, Flura M, Mathews S, Strehler-Page MA, Krebs J, Penniston JT, Carafoli E \& Strehler EE 1988 Multiple divergent mRNAs code for a single human calmodulin. Journal of Biological Chemistry 263 17055-17062.

Juhlin CC, Kiss NB, Villablanca A, Haglund F, Nordenstrom J, Hoog A \& Larsson C 2010 Frequent promoter hypermethylation of the APC and RASSF1A tumour suppressors in parathyroid tumours. PLoS ONE $\mathbf{5}$ e9472. (doi:10.1371/journal.pone.0009472)

Kato M, Hagiwara M, Nimura Y, Shionoya S \& Hidaka H 1991 Purification and characterization of calcium-calmodulin kinase II from human parathyroid glands. Journal of Endocrinology 131 155-162. (doi:10.1677/ joe.0.1310155)

Kifor O, MacLeod RJ, Diaz R, Bai M, Yamaguchi T, Yao T, Kifor I \& Brown EM 2001 Regulation of MAP kinase by calcium-sensing receptor in bovine parathyroid and CaR-transfected HEK293 cells. American Journal of Physiology. Renal Physiology 280 F291-F302.

Kinder BK, Delahunt NG, Jamieson JD \& Gorelick FS 1987 Calciumcalmodulin-dependent protein kinase in hyperplastic human parathyroid glands. Endocrinology 120 170-177. (doi:10.1210/endo-120-1-170)

Lang J, Fukuda M, Zhang H, Mikoshiba K \& Wollheim CB 1997 The first $\mathrm{C} 2$ domain of synaptotagmin is required for exocytosis of insulin from pancreatic $\beta$-cells: action of synaptotagmin at low micromolar calcium. EMBO Journal 16 5837-5846. (doi:10.1093/emboj/16.19.5837)

Liao WC, Huang CC, Cheng HH, Wang JL, Lin KL, Cheng JS, Chai KL, Hsu PT, Tsai JY, Fang YC et al. 2009 Effect of calmidazolium on $\left[\mathrm{Ca}^{2+}\right]_{\mathrm{i}}$ and viability in human hepatoma cells. Archives of Toxicology 83 61-68. (doi:10.1007/s00204-008-0328-4)

Lu M, Forsberg L, Hoog A, Juhlin CC, Vukojevic V, Larsson C, Conigrave AD, Delbridge LW, Gill A, Bark C et al. 2008 Heterogeneous expression of SNARE proteins SNAP-23, SNAP-25, Syntaxin1 and VAMP in human parathyroid tissue. Molecular and Cellular Endocrinology 287 72-80. (doi:10. 1016/j.mce.2008.01.028)

Lu M, Bränström R, Berglund E, Hoog A, Bjorklund P, Westin G, Larsson C, Farnebo LO \& Forsberg L 2010 Expression and association of TRPC subtypes with Orai1 and STIM1 in human parathyroid. Journal of Molecular Endocrinology 44 285-294. (doi:10.1677/JME-09-0138)

Nemeth EF, Wallace J \& Scarpa A 1986 Stimulus-secretion coupling in bovine parathyroid cells. Dissociation between secretion and net changes in cytosolic $\mathrm{Ca}^{2+}$. Journal of Biological Chemistry 261 2668-2674.

Oldham SB, Lipson LG \& Tietjen GE 1982 Presence of calmodulin in parathyroid adenomas. Mineral and Electrolyte Metabolism 7 273-280.

Schlatterer C \& Schaloske R 1996 Calmidazolium leads to an increase in the cytosolic $\mathrm{Ca}^{2+}$ concentration in Dictyostelium discoideum by induction of $\mathrm{Ca}^{2+}$ release from intracellular stores and influx of extracellular $\mathrm{Ca}^{2+}$. Biochemical Journal 313 661-667.

Schweitzer ES, Sanderson MJ \& Wasterlain CG 1995 Inhibition of regulated catecholamine secretion from PC12 cells by the $\mathrm{Ca}^{2+} /$ calmodulin kinase II inhibitor KN-62. Journal of Cell Science 108 2619-2628.

Shoback D, Thatcher J, Leombruno R \& Brown E 1983 Effects of extracellular $\mathrm{Ca}^{++}$and $\mathrm{Mg}^{++}$on cytosolic $\mathrm{Ca}^{++}$and PTH release in dispersed bovine parathyroid cells. Endocrinology 113 424-426. (doi:10. 1210/endo-113-1-424)

Shoback DM, Thatcher J, Leombruno R \& Brown EM 1984 Relationship between parathyroid hormone secretion and cytosolic calcium concentration in dispersed bovine parathyroid cells. PNAS 81 3113-3117. (doi:10. 1073/pnas.81.10.3113) 
Stefani G, Onofri F, Valtorta F, Vaccaro P, Greengard P \& Benfenati F 1997 Kinetic analysis of the phosphorylation-dependent interactions of synapsin I with rat brain synaptic vesicles. Journal of Physiology 504 501-515. (doi:10.1111/j.1469-7793.1997.501bd.x)

Vaca L 1996 Calmodulin inhibits calcium influx current in vascular endothelium. FEBS Letters 390 289-293. (doi:10.1016/00145793(96)00675-8)

Vaca L \& Sampieri A 2002 Calmodulin modulates the delay period between release of calcium from internal stores and activation of calcium influx via endogenous TRP1 channels. Journal of Biological Chemistry 277 42178-42187. (doi:10.1074/jbc.M204531200)

Wang ZW 2008 Regulation of synaptic transmission by presynaptic CaMKII and BK channels. Molecular Neurobiology 38 153-166. (doi:10.1007/s12035008-8039-7)

Watanabe H, Takahashi R, Tran QK, Takeuchi K, Kosuge K, Satoh H, Uehara A, Terada H, Hayashi H, Ohno R et al. 1999 Increased cytosolic
$\mathrm{Ca}(2+)$ concentration in endothelial cells by calmodulin antagonists. Biochemical and Biophysical Research Communications 265 697-702. (doi:10. 1006/bbrc.1999.1755)

Yamamoto H, Matsumoto K, Araki E \& Miyamoto E 2003 New aspects of neurotransmitter release and exocytosis: involvement of $\mathrm{Ca}^{2+} /$ calmodulin-dependent phosphorylation of synapsin I in insulin exocytosis. Journal of Pharmacological Sciences 93 30-34. (doi:10. 1254/jphs.93.30)

Received in final form 29 September 2010

Accepted 22 October 2010

Made available online as an Accepted Preprint 25 October 2010 